\title{
PRONOME DE INTERESSE E OUTROS PRONOMES EM FUNÇÃO EMOTIVA
}

A bstract. Mikołajczak Sylwia, Pronome de interesse e outros pronomes em funçâo emotiva [Pronoun of interest and other pronouns of emotive function]. Studia Romanica Posnaniensia, Adam Mickiewicz University Press, Poznań, vol. XXXVI: 2009, pp. 111-115. ISBN 978-83-232-20350. ISSN 0137-2475.

The pronoun in spite of its various marking functions has some uses that can be considered slightly marginal. The aim of this article is to illustrate pronouns in its emotive and affective usage. The following text is aimed to evidence that either personal or objective form of a pronoun is able to complete such functions that can mean "delicate" semantic relations without any reference to the functions considered crucial for pronominal form such as anaphor, possession, noun substitution, etc.

\section{INTRODUÇÃO}

O pronome abrange uma classe de vocábulos extremamente vasta com uma multidâo de usos e realizações. Em geral, os pronomes desempenham na frase as funções equivalentes às empregadas pelos elementos nominais. Por um lado, servem para representar um substantivo para evitar a repetição do tal. Por outro lado, os pronomes costumam acompanhar o substantivo, determinando-lhe a extensão do significado (demonstrativos, possessivos).

\section{AS FUNÇÕES BÁSICAS DO PRONOME}

Sendo um elemento tão multifuncional, o pronome desempenha papéis claramente definidos. As suas funções principais são as de:

- substituir o substantivo (p.ex. para evitar a sua repetição) - função contextualizada - não substituem qualquer substantivo, só um determinado e num determinado contexto. Os pronomes representam, determinam e esclarecem, o que sugere 
que deviam transmitir a informação já conhecida. Apesar disso, para cumprir a função anafórica, que os pronomes desempenham com frequência, é preciso o elemento comunicado ter sido anteriormente expresso. Em outras palavras, a referência anafórica permitia a passagem de uma ideia à sua representação, somente sob a condição que essa existisse na consciência do interlocutor. Essa referência faz-se frequentemente por meio do pronome:

1. Este trabalho, eu não quis fazê-lo.

2. Vi o João na rua, chamei-o mas ele não me respondeu.

- modificar substantivos (função de adjectivo, possessivos, demonstrativos),

- marcar os participantes do acto comunicativo (pessoais),

- marcar as relações entre os participantes de comunicação (complementos, recíprocos) e entre os participantes e o elemento comunicado (possessivos), tivos).

- indicação deíctica (posição e relação no espaço e no tempo) (demonstra-

Pronombres demostrativos. Son aquellos con que se muestra un objeto, o varios, entre todos los de su especie, indicando su proximidad o lejanía respecto de la persona que habla o de aquella a quien se habla (RAE, 1996: 214).

\section{O PRONOME E AS SUAS FUNÇÕES EMOTIVAS}

O pronome, sendo o elemento definido pelos falantes, facilita a comunicação fazendo esta mais rápida, mas ao mesmo tempo mais clara. Abstraindo do facto de o pronome ser um instrumento da economia da linguagem, este costuma aparecer em casos onde a sua ocorrência não é sintacticamente clara, nem justificada, e estes casos em particular constituem o campo do nosso discurso. Em outras palavras, neste artigo não pretendemos ocupar-nos das funções mais comuns dos pronomes, mas, ao contario, tencionamos dedicar mais atenção aos papéis raramente por eles desempenhados.

Um deles constitui uma mistura de funções afectiva e enfática. Daí resulta que o pronome pode ser empregado com sucesso com o fim de pôr uma marca afectiva independentemente da forma em que aparece. Primeiro, vejamos o pronome na sua forma pessoal.

\subsection{PRONOME PESSOAL}

Não faltam os enunciados onde o pronome pessoal traz uma grande carga expressiva. Podemos comparar os exemplos:

3. ; Cállate, tú!

4. ¡ Tú, cállate! 
5. ¡Tú, quédate aquí!

6. ¡ Tú, tómate una copa!

7. Cala-te, tu!

8. Tu, cala-te!

onde se mantém o pronome para intensificar o significado e a insistência da ordem. A mesma presença do pronome não é necessária do ponto de vista de sintáctica, assim que a forma verbal aclara muito bem o receptor da mensagem.

No caso da proibição, igual que nas ordens fortes, o uso dos pronomes intensifica o valor expressivo dos enunciados. Vejamos o exemplo:

9. ¡ No te atrevas tú hablarme así!

\subsection{O PRONOME - OBJECTO INDIRECTO}

O pronome na forma de objecto indirecto aparece com frequência na forma de pronome de interesse (também conhecido como dativo ético ou de proveito) (Cunha, Cintra, 2001: 219).

Nas frases:

10. Olhem-me para ela: é o espelho de donas de casa!

11. Mas o Daniel já nẫo é assim. Aquilo é outra mâe [...] Um dia de ceifa é bastante para mo matar. (As Pupilas do Senhor Reitor, Júlio Dinis)

A forma mo é a contracção de dois pronomes pessoais: me e $o$. O pronome me não desempenha nenhuma função sintáctica. Trata-se de um recurso expressivo que se emprega quando se pretende evidenciar o interesse que o emissor tem no assunto. No caso desta frase, o que acontecesse ao filho (morrer) era como se lhe acontecesse a ele, ao pai. Poderia ter sido utilizada a frase "Um dia de ceifa é bastante para o matar", mas nesta frase não se notaria tanta preocupação do pai em relação ao filho.

Também, no ex. 10 o emissor não expressa o desejo de olharem para ele, então a função do pronome "me" não concorda com nenhuma mencionada antes. O que a pessoa que fala quer mostrar é o seu vivo interesse no cumprimento da ordem emitida, mas também a sua atitude emocional perante a mensagem comunicada. Observem o mesmo uso em outros casos, desta vez na língua polaca:

\section{Uciekaj mi stąd!}

A direcção a que se aplica a ordem é contrária da implicada pelo pronome objecto indirecto "mi". O elemento pronominal, igual que no exemplo 10 , indica o estado emocional do falante e a sua forte insistência no cumprimento do imperativo.

Em relação com o seu cargo expressivo, o pronome de interesse é de uso frequente na linguagem coloquial ou nos textos literários. 
A preocupação parecida observa-se nas frases do tipo:

13. Faleceu-me o marido.

Também presentes no polaco:

14. Umarł mi mąż.

O pronome neste caso implica certa intimidade ou proximidade na relação entre a pessoa que fala e a pessoa de que se fala. Talvez, por isso a frase: "Faleceu o meu marido", já careça de uma subtil implicação emocional que mostra o exemplo 13.

No exemplo seguinte:

15. Imaginem - explica Don Giuliano - que vos entram no panteẫo da família, retiram as lápides e abrem os túmulos dos vossos antepassados. (Revista Super, n. ${ }^{\circ} 56,2002$ )

fica bem claro que os malfeitores não entram no túmulo de Don Giuliano, como este continua vivo, más a relação emocional que ele tem perante os túmulos dos membros da sua família vê-se aqui expressa no uso do pronome "vos". "Imaginem que vos entram nos túmulos da vossa família como tinham entrado nos da minha".

\subsection{O PRONOME POSSESSIVO}

Os pronomes possessivos, cujo papel principal é acrescentar à noção de pessoa gramatical a ideia de posse, em certas expressões obtêm uma carga afectiva ou emotiva. O pronome possessivo pode expressar vários matizes afectivos. Vejam o emprego dos pronomes possessivos nas seguintes frases:

16. Tu és digna, filha minha! (Machado de Assis, 1959: 672)

Em espanhol observa-se o mesmo uso:

17. ¡Hijo mío, hijo mío!

Neste caso, vemos como os possessivos têm assumido outros valores na língua moderna, por exemplo, para designar hábitos ou aproximação. Sente-se nos possessivos, uma certa carga afectiva que serve por vezes para acentuar sentimentos. Com entoação especial pode expressar toda a gama de sentimentos - ironia, sarcasmo, amor, p.ex.:

18. Ó meu amigo. (simpatia)

19. Essas suas amiguinhas! (sarcasmo)

20. Sem você, meu Amor, eu nẫo sou ninguém. (amor)

21. Te jego chimery. (sarcasmo) 
Devíamos mencionar também o uso especial, característico do português, dos pronomes possessivos da terceira pessoa seu/seus com o substantivo nas expressões com o claro valor emotivo, muitas vezes ofensivo:

22. Seu idiota!

23. Sua estúpida!

24. Sua desvergonhada!

\subsection{PRONOME DEMONSTRATIVO}

Pronomes demonstrativos podem servir para intensificar ironia, desprezo ou sarcasmo:

25. - Este rapaz. Este rapaz.

26. Ach, ten Wojtek.

\section{PALAVRAS FINAIS}

Apesar de apresentarem múltiplas funçōes reconhecidas como sintácticamente essenciais, os pronomes podem desempenhar outros papéis no subtil nível semántico da frase. As suas características expressivas ajudam-as a formarem enunciados com uma grande carga emotiva ou afectiva que podem funcionar como indicador de toda a gama de emoções ou grau de proximidade entre o emissor e o tema da mensagem comunicada. Assim, o pronome não se limita às puras funções sintácticas.

\section{BIBLIOGRAFIA}

Cunha C., Lindley C. (2001), Breve Gramática do Portuguềs Contemporâneo, Lisboa : Ediçōes João Sá de Costa.

Dapena A.P. (1986), Los Pronombres, Madrid : Edi-6 S.A.

Drabik B. (2004), Komplement i komplementowanie jako akt mowy, Kraków : Universitas.

Machado de Assis J. (1959), Obra completa. Rio de Janeiro.

Perlin J. (1988), Gramatyka języka portugalskiego, Warszawa : PWN.

RAE (1996), Esbozo de una nueva gramática española, Madrid : Espasa Calpe, "Enigmas Genéticos", Revista Super, $n^{\circ}$ 56, 2002. 